\title{
Profil Pencapaian Keterampilan Proses Sains dan Peningkatan KemampuanKognitif Siswa Kelas X dalam Pembelajaran Fisika dengan bantuan LKS Inquiry Activity Berbasis Model Pembelajaran Curious Note Program (CNP)
}

\author{
Fatimah Primadian Farumananda ${ }^{1}$, Agus Yulianto ${ }^{2}$, Budi Astuti ${ }^{3}$
}

\begin{abstract}
This study aims to determine the profile of achievement of students 'science process skills and students' cognitive abilities improvement in physics learning with the help LKS Inquiry Activity based on CNP learning model. The study design used was a One Group Pretest-Posttes Design. Subject this research is students of class X SMA Negeri 7 Yogyakarta amounting to 32 students. The data were collected by using test instruments in the form of pretest-postes, LKS Inquiry Activity based on CNP learning model, and student response questionnaire. The profile of students 'science skill achievement can be determined from the scores criteria scores 5. The results obtained after using LKS Inquiry Activity based on CNP learning model that is the achievement profile of students' science process skill in Finding Out Question, Discussion And Determination And Study Related Theory is included in the good category with a score of 4.00, 4.11 and 3.53, respectively. For the Inquiry Activity skill, it is categorized as excellent with a score of 4.50. Meanwhile, students' cognitive abilities increased with an average score of 4.32 with good category. Students' responses to LKS Inquiry Activity based on the CNP learning model earned a grade of 3.57 in either category. It indicates that LKS Inquiry Activity based on CNP learning model can know the profile of the achievement of science process skill.
\end{abstract}

Keywords: Science Process skill, Cognitive Ability, CNP Learning Model 


\section{Abstrak}

Penelitian ini bertujuan untuk mengetahui profil pencapaian keterampilan proses sains siswa dan peningkatan kemampuan kognitif siswa dalam pembelajaran fisika dengan bantuan LKS Inquiry Activity berbasis model pembelajaran CNP. Desain penelitian yang digunakan adalah One Group Pretest-Posttes Design. Subjek penelitian ini adalah siswa kelas X SMA Negeri 7 Yogyakarta berjumlah 32 siswa. Pengambilan data dilakukan dengan menggunakan instrumen tes berupa soal pretes-postes, LKS Inquiry Activity berbasis model pembelajaran CNP, dan angket respon siswa. Profil peencapaian keterampilan sains siswa dapat diketahui dari hasil kriteria penskoran skala 5. Hasil penelitian yang diperoleh setelah menggunakan LKS Inquiry Activity berbasis model pembelajaran CNP yaitu profil pencapaian ketrampilan proses sains siswa dalam Finding Out Question, Discussion And Determination And Study Related Theory masuk dalam kategori baik dengan skor masing masing adalah 4,00, 4,11, dan 3,53. Untuk keterampilan Inquiry Activity masuk dalam kategori sangat baik dengan skor 4,50. Sementara itu, kemampuan kognitif siswa mengalami peningkatan dengan skor nilai rata-rata sebesar 4.32 dengan kategori baik. Tanggapan siswa terhadap LKS Inquiry Activity berbasis model pemelajaran CNP memperoleh nilai sebesar 3.57 dalam kategori baik. Hal tersebut mengindikasikan bahwa LKS Inquiry Activity berbasis model pembelajaran CNP dapat mengetahui profil pencapaian ketrampilan proses sains.

Kata kunci: Keterampilan Proses Sains, Kemampuan Kognitif, Model Pembelajaran CNP

\section{PENDAHULUAN}

Mata pelajaran fisika adalah salah satu mata pelajaran yang diajarkan pada jenjang pendidikan Sekolah Menengah Atas (SMA). Mata pelajaran fisika merupakan bagian dari sains yang mempelajari fenomena dan gejala alam secara empiris, logis, sistematis, dan rasional yang melibatkan proses dan sikap ilmiah (Mundilarto, 2002) pada dasarnya, pembelajaran fisika ditingkat SMA bertujuan agar siswa memiliki kemampuan sebagai berikut: 1) membentuk sikap positif dengan menyadari keindahan dan keteraturan alam untuk meningkatkan keyakinan terhadap Tuhan YME; 2) Memupuk sikap ilmiahnya mencakup jujur, objektif terhadap data, terbuka dalam menerima pendapat berdasarkan bukti-bukti tertentu, kritis terhadap pernyataan ilmiah dan dapat bekerja sama dengan orang lain; 3) memberi pengalaman untuk data mengajukan dan menguji hipotesis melalui percobaan, merancang dan merakit instrument percobaan, mengumpulkan, mengolah dan menafsirkan data, menyusun laporan serta mengkomunikasikan hasil percobaan secara tertulis dan lisan; 4) Mengembangkan kemampuan berfikir analisis induktif dan deduktif dengan 
Fatimah Primadian Farumananda, Agus Yulianto, Budi Astuti / Phenomenon Vol. 08, No. 1, Juli 2018 menggunakan konsep dan prinsip fisika untuk menjelaskan berbagai peristiwa alam dan menyelesaikan masalah secara kualitatif maupun kuantitatif; 5) Menguasai pengetahuan,konsep dan prinsip fisika, serta memiliki pengetahuan dan keterampilan bersikap ilmiaih (Depdiknas, 2006)

Berdasarkan uraian diatas seharusnya mata pelajaran fisika di SMA dilaksanakan dengan metode pembelajaran yang dapat membantu para siswa untuk tidak hanya dapat menguasai pengetahuan, konsep, dan prinsip fisika saja, melainkan dapat melatih para siswa agar dapat memiliki keterampilan dan sikap ilmiah. Salah satu keterampilan yang dimaksud adalah keterampilan proses sains.

Keterampilan proses sains perlu dilatih dan dikembangkan karena keterampilan proses sains siswa berperan dalam membantu siswa mengembangkan pikirannya, memberi kesempatan kepada siswa untuk melakukan penemuan, meningkatkan daya ingat, memberikan kepuasan instriksik bila anak telah berhasil melakukan sesuatu, dan membantu siswa mempelajari konsep-konsep sains (Indrawati, 1999). Penelitian lain mengungkapkan dengan mengembangkan keterampilan proses, peserta didik akan mampu menemukan dan mengembangkan sendiri fakta dan konsep serta menumbuhkan dan mengembangkan sikap dan nilai yang dituntut (Semiawan, C., 1992). Dengan melakukan sendiri siswa akan lebih menghayati, berbeda halnya jika hanya mendengar atau sekedar membaca. Berdasarkan pernyataan tersebut, maka perlu identifikasi kemampuan keterampilan proses sains sehingga dapat memperoleh gambaran perolehan konsep-konsep sains pada peserta didik berdasarkan proses.

Berdasarkan data yang diperoleh dari hasil observasi peneliti di SMA N 7 Yogyakarta diketahui bahwa mata pelajaran fisika merupakan mata pelajaran yang memiliki nilai ketuntasan tinggi. Selama ini, masih banyak nilai siswa belum mencapai nilai KKM yaitu 75. Hal ini ditunjukkan dengan nilai rata-rata siswa kelas X-7 sebesar 64. Dari jumlah keseluruhan siswa hanya beberapa siswa yang mendapatkan nilai diatas KKM sedangkan masih banyak siswa yang memperoleh nilai dibawah KKM yaitu antara 50-73. Selain itu, media pembelajaran yang digunakan pada saat proses pembelajaran masih berupa LKS yang bersifat umum dan cenderung dijadikan sebagai bahan acuan atau sumber belajar utama, kegiatan laboratorium pun jarang sekali dilakukan. Berdasarkan hasil wawancara dengan guru, metode pembelajaran yang sering digunakan adalah metode ceramah dan diskusi/Tanya jawab, sebagian siswa 
Fatimah Primadian Farumananda, Agus Yulianto, Budi Astuti / Phenomenon Vol. 08, No. 1, Juli 2018 masih merasa kesulitan untuk berdiskusi dengan sekelompoknya. Sehingga aktivitas tersebut cenderung didominasi oleh siswa yang memiliki pemahaman yang lebih tinggi. Akibatnya siswa yang memiliki pemahaman rendah menjadi kurang aktif. Pembelajaran dengan metode ceramah yang dilakukan oleh guru cenderung membuat siswa tidak berperan aktif dalam menemukan atau membangun suatu konsep yang sedang dipelajari, sehingga membuat siswa merasa cepat bosan.

Untuk mengatasi masalah-masalah tersebut, maka diperlukan suatu model pembelajaran yang dapat memebantu siswa untuk berperan aktif dalam mencapai keterampilan proses sains siwa. Salah satu model pembelajaran yang bisa digunakan adalah model pembelajaran Curious Note Program (CNP).

Model pembelajaran CNP adalah model pembelajaran yang menerapkan pendekatan inkuiri mandiri yang mengarahkan siswa untuk melakukan tahap-tahap yang telah ditentukan dalam model pembelajaran CNP (Semiawan, C., 1992). Model ini masih terbilang baru dalam dunia pendidikan khususnya di Indonesia. Model pembelajaran CNP sudah dikembangkan dan dilaksanakan di sekolah Korea, contohnya KNU SEIGY (Science Education Institute for Gifted Youth).

Pembelajaran yang menerapkan model CNP dikembangkan dengan menggunakan LKS. Salah satu jenis LKS yang digunakan dalam model pembelajaran CNP ini adalah LKS berbentuk Inquiry Activity. Hasil penelitian yang dilakukan Kinanti (2015) menunjukkan bahwa LKPD Study Related Theory layak digunakan dalam pembelajaran fisika dan memperoleh katagori sangat baik dilihat dari analisis validitas CVI LKPD Study Related Theory sebesar 1 (sangat baik) dan hasil respon peserta didik memperoleh nilai CVI 0,67 (sangat baik), serta reliabel menurut ICC LKPD (istimewa) dan PA [6]. Selain itu, LKPD yang dikembangakna oleh Purwoko (2015) mampu memfasilitasi siswa SMA dalam merancang eksperimen pada materi hukum Newton tentang Gravitasi.

Penelitian ini mengambil salah satu materi fisika SMA kelas $X$ yaitu Suhu dan Kalor. Ini disebabkan saat melakukan proses belajar dan mengajar yang berlangsung di kelas materi Suhu dan Kalor, LKS yang digunakan masih berupa LKS yang hanya berisi rangkuman materi, rumus singkat dan latihan soal serta dalam prosesnya guru hanya menggunakan metode ceramah saja. Hal ini membuktikan bahwa siswa tidak ikut andil dalam proses belajar mengajar dan lagi-lagi iswa yang memiliki kemampuan tinggi 
Fatimah Primadian Farumananda, Agus Yulianto, Budi Astuti / Phenomenon Vol. 08, No. 1, Juli 2018 lebih mendominasi. Selain itu, materi Suhu dan Kalor merupakan salah satu materi yang dekat dengan kehidupan siswa dan banyak masalah yang timbul dalam kehidupan sehari-hari sehingga sangat cocok diterapkannya model pembelajaran berbasis CNP pada materi tersebut.

Berdasarkan uraian di atas, fokus penelitian ini adalah untuk mengetahui profil pencapaian keterampilan proses siswa dan peningkatan kemampuan kognitif siswa dalam pembelajaran fisika dengan bantuan LKS Inquiry Activity berbasis model pembelajaran Curious Note Program (CNP) pada materi Suhu dan Kalor. Hasil penelitian ini diharapkan dapat dapat dijadikan bahan pertimbangan bagi guru dan calon guru dalam melaksanakan pembelajaran di sekolah. Hasil penelitian ini juga dapat dijadikan sebagai bahan kajian bagi penelitian selanjutnya yang berhubungan dengan masalah ini, sehingga hasilnya dapat lebih luas dan mendalam serta mendapatkan kejelasan.

\section{METODE PENELITIAN}

Metode yang digunakan dalam penelitian ini adalah metode pre experimental design atau eksperimen yang tidak sebenarnya (Arikunto, S., 2006). Desain penelitian yang digunakan dalam penelitian ini adalah desain One Group Pretest Posttest Design. Subjek penelitian yang digunakan adalah siswa kelas X SMA Negeri 7 Yogyakarta, sebanyak 32 siswa. Instrumen penelitian ini menggunakan soal pretes-postes, LKS Inquiry Activity berbasis model pembelajaran CNP, dan angket respon siswa. Soal pretes-postes digunakan untuk mengetahui peningkatan kemampuan kognitif siswa. LKS Inquiry Activity berbasis model pembelajaran CNP digunakan untuk menilai profil pencapaian keterampilan proses sains siswa dalam tahap-tahap yang ada pada model pembelajaran CNP. Angket respon siswa digunakan untuk mengetahui respon siswa terhadap LKS Inquiry Activity berbasis model pembelajaran CNP yang digunakan pada proses pembelajaran.

Analisis data yang dilakukan meliputi hasil pretes dan posttes, angket respon siswa dan hasil pengerjaan siswa terhadap LKS Inquiry Activity berbasis model pembelajaran CNP. Teknik analisis data dilakukan dengan menggunakan penilaian skor skala 5 menurut (Widiyoko, Eko P., 2011) yang mengkonversi hasil penilaian menjadi data kuantitatif dengan langkah sebagai berikut: 
Fatimah Primadian Farumananda, Agus Yulianto, Budi Astuti / Phenomenon Vol. 08, No. 1, Juli 2018

1) Menghitung rata-rata skor dari setiap komponen aspek penilaian dengan menggunakan rumus:

$$
\bar{x}=\frac{\Sigma x}{n}
$$

Keterangan

$\mathrm{x}=$ skor rata-rata

$\sum \mathrm{x}=$ jumlah skor

$\mathrm{n}=$ jumlah penilai

2) Mengkonversi skor menjadi skala nilai 5 dan kemudian dicocokkan berdasarkan table 1 .

Tabel 1. Kriteria Penilaian Penelitian dalam Skala 5

\begin{tabular}{ll}
\hline Rentang rata- rata skor & Kategori \\
\hline$X>4,26$ & Sangat Baik \\
$3,42<X \leq 4,26$ & Baik \\
$2,58<X \leq 3,42$ & Cukup Baik \\
$1,74<X \leq 2,58$ & Kurang Baik \\
$X \leq 1,74$ & Sangat Kurang Baik \\
\hline
\end{tabular}

Besar kriteria nilai skala 5 yang diperoleh menunjukkan besar pencapaian profil keterampilan proses sains siswa dengan bantuan LKS Inquiry Activity berbasis model pembelajaran CNP.

\section{HASIL DAN PEMBAHASAN}

Pelaksanaan pembelajaran dengan menggunakan LKS Inquiry Activity berbasis model pembelajaran CNP dilakukan melalui beberapa tahap diantaranya:

1. Tahap Finding Out Question

Pada tahap ini diawali dengan memperlihatkan sebuah fenomena yang berhubungan dengan kehidupan sehari-hari. Dari fenomena, siswa diajak untuk mencari masalah dan merumuskan masalah yang diperoleh menjadi beberapa pertanyaan serta menuliskannya kedalam LKS. Pada awalnya siswa merasa kesulitan untuk merumuskan pertanyaan karena siswa tidak terbiasa melakukan hal tersebut. Namun, setelah 
Fatimah Primadian Farumananda, Agus Yulianto, Budi Astuti / Phenomenon Vol. 08, No. 1, Juli 2018 diberikan arahan sebagian siswa mampu membuat pertanyaan yang diharapkan. Hal ini sesuai dengan yang dikatakan Sanjaya (2007) bahwa siswa akan memiliki motivasi belajar yang tinggi manakala dilibatkan secara langsung dalam merumuskan masalah yang akan dikaji.

\section{Tahap Discussion and Determination}

Pada tahap ini siswa diminta untuk merancang sebuah eksperimen yang berhubungan dengan pertanyaan yang telah ditulis sebelumnnya. Mulai dari menjawab beberapa pertanyaan yang nantinya akan mengarahkan siswa dalam menuliskan judul eksperimen yang akan dirancang, menentukan variabel, menentukan alat dan bahan, langkah kerja sampai dengan membuat tabulasi data.

\section{Tahap Study Related Theory}

Pada tahap ini siswa diminta untuk membuat jawaban sementara atau hipotesis atas pertanyaan dan rancangan eksperimen yang telah ditentukan. Pada saat siswa berhipotesis, diharakan siswa memahami bahwa hipotesis yang mereka buat harus dibuktikan. Didukung dengan adanya penyusunan kajian teori yang dapat membantu siswa untuk memperkuat hipotesis, mengumpulkan data-data, menambahkan atau memperbaiki eksperimen yang sudah dirancang serta menarik kesimpulan.

\section{Tahap Inquiry Activity}

Pada tahap ini siswa diminta untuk menguatkan kembali rancangan eksperimen mereka sebelum mereka melakukan eksperimen, selanjutnya pelaksanaan eksperimen dan hasil analisis. Pada tahap ini siswa berdiskusi melakuakan analisis data dari hasil eksperimen yang telah dilakukan serta menghubung-hubungkan data yang diperoleh dengan teori yang di dapat pada tahap sebelumnya sehingga siswa menemukan suatu pola tertentu. Selanjutnya, guru memberikan arahan kepada siswa untuk menarik kesimpulan dari apa yang telah dilakukan pada tahap-tahap sebelumnya. Kemudian menggeneralisasikan dan melakukan refleksi terhadap apa yang telah dilakukan dan diperoleh.

\section{Keterampilan Proses Siswa}

1. Keterampilan Proses Siswa pada tahap Finding Out Question

Data hasil pengolahan skor kriteria penilaian skala 5 dapat dilihat pada Gambar 1. 
Fatimah Primadian Farumananda, Agus Yulianto, Budi Astuti / Phenomenon Vol. 08, No. 1, Juli 2018

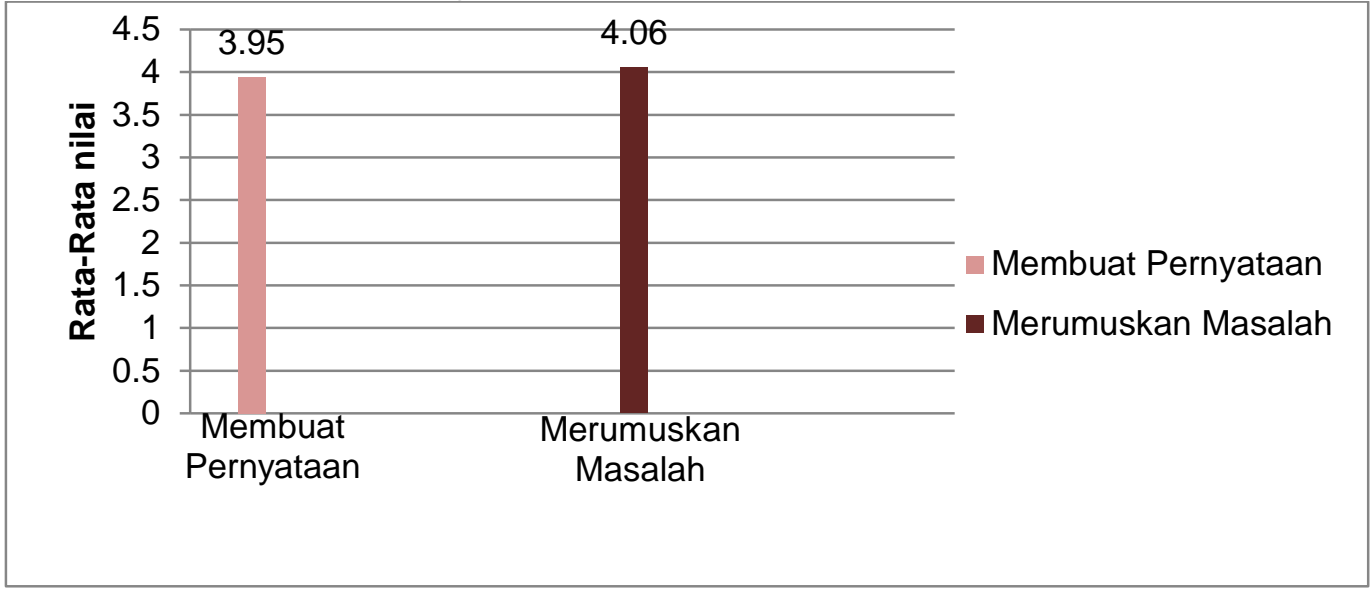

Gambar 1. Profil Pencapaian Keterampilan Proses Siswa pada tahap Finding Out Question

Berdasarkan Gambar 1 tampak bahwa pada tahap Finding Out Question memiliki skor rata-rata dalam membuat pernyataan sebesar 3,95 sementara dalam merumuskan masalah sebesar 4,06 masuk dalam kategori baik. Hal ini menunjukkan bahwa tercapainya keterampilan proses sains siswa pada tahap Finding Out Question.

Keterampilan Proses Siswa dianaisis lebih lanjut yaitu pada tahap selanjutnya yaitu tahap Discussion and Determination.

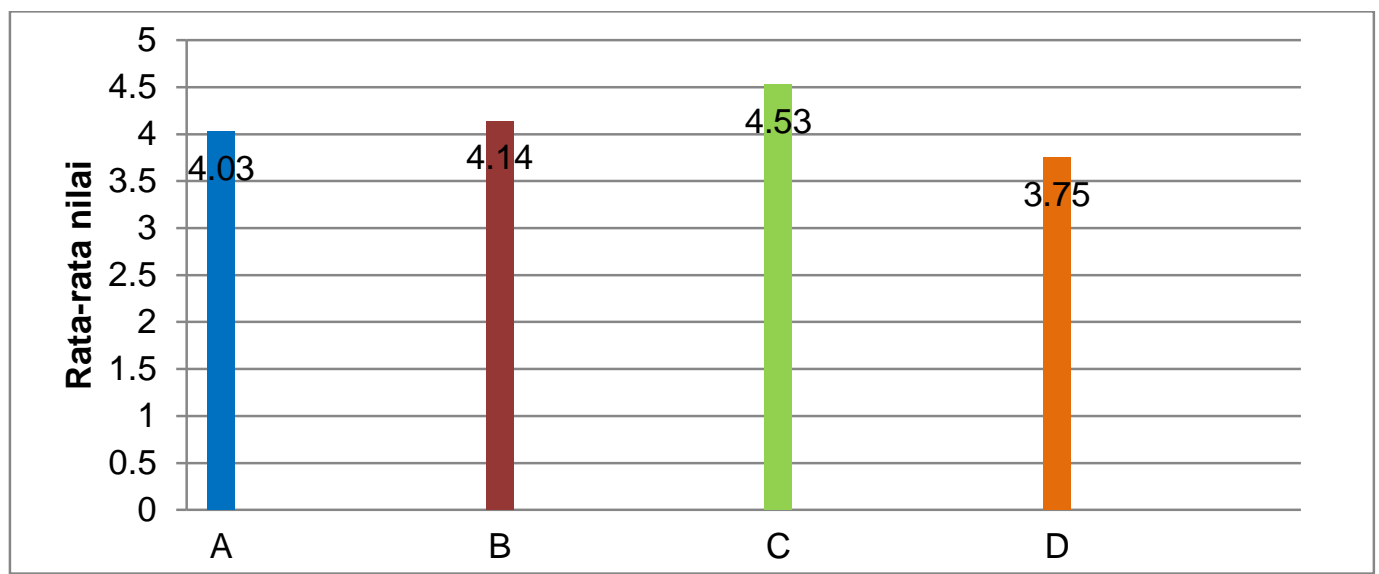

Gambar 2. Profil Pencapaian Keterampilan Proses Siswa pada tahap

Discussion and Determination

Keterangan:

A : Membuat Judul

B : Identifikasi Variabel

C : Menentukan Alat dan Bahan

D : Membuat Tabulasi Data 
Fatimah Primadian Farumananda, Agus Yulianto, Budi Astuti / Phenomenon Vol. 08, No. 1, Juli 2018

Berdasarkan data pada Gambar 2 tampak bahwa perolehan skor pada keterampilan proses sains dalam menentukan alat dan bahan mendapatkan skor tinggi diantara keterampilan proses sains yang lain pada tahap Discussion and Determination yaitu sebesar 4.53 kategori sangat baik. Sedangkan perolehan skor rendah terletak pada keterampilan proses sains dalam membuat tabulasi data yaitu sebesar 3.75 kategori baik.

Pencapaian keterampilan proses sains dianalisis lebih lanjut ke tahap selanjutnya yaitu, Study Related Theory

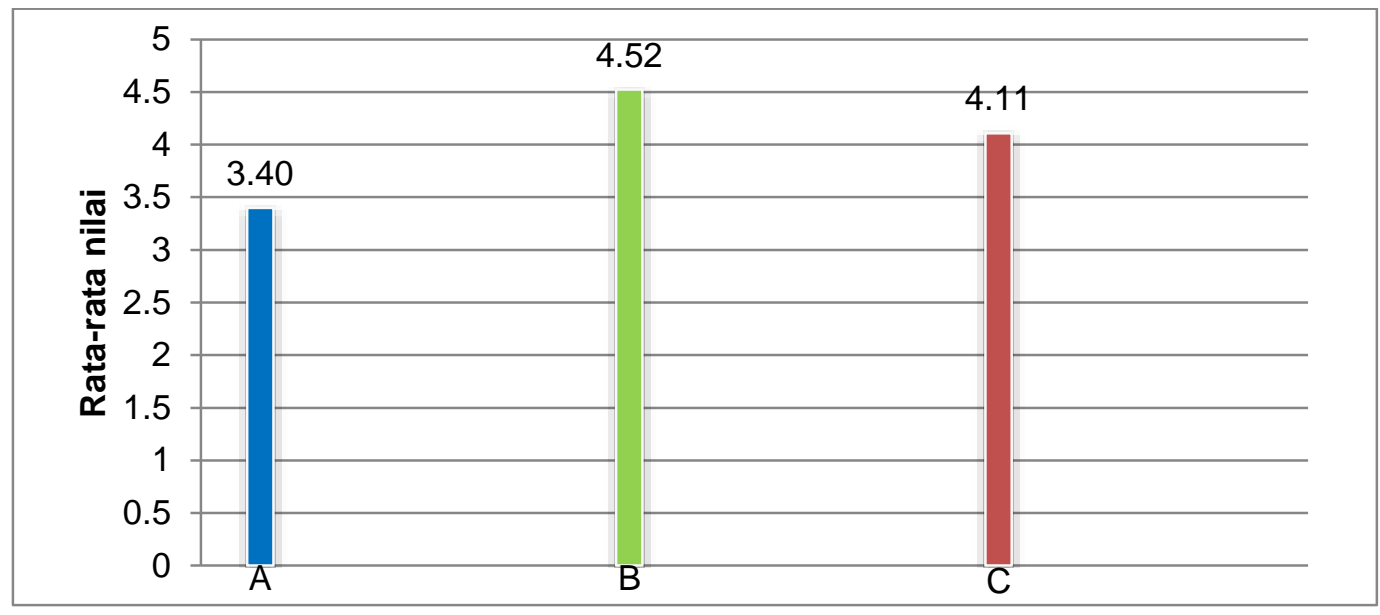

Gambar 3. Profil Pencapaian Keterampilan Proses Siswa pada tahap Study Related Theory

Keterangan:
A : Meyusun Hipotesis
B : Membuat Kajian Teori
$\mathrm{C}:$ Menjawab Pertanyaan

Berdasarkan data pada Gambar 3 tampak bahwa perolehan skor pada keterampilan proses sains dalam membuat kajian teori mendapatkan skor tinggi diantara keterampilan proses sains yang lain pada tahap Study Related Theory yaitu sebesar 4.52 kategori sangat baik. Sebab siswa bisa memperoleh informasi sebanyak-banyaknya dari berbagai media yang telah disediakan. Sedangkan perolehan skor rendah terletak pada merumuskan hipotesis yaitu sebesar 3.40 kategori cukup baik. Hal ini dikarenakan pada saat merumuskan hipotesis siswa masih merasa kebingungan dengan eksperimen yang 
Fatimah Primadian Farumananda, Agus Yulianto, Budi Astuti / Phenomenon Vol. 08, No. 1, Juli 2018 dirancang pada tahap sebelumnya.

Pencapaian keterampilan proses sains dianalisis lebih lanjut ke tahap selanjutnya yaitu, Inquiry Activity

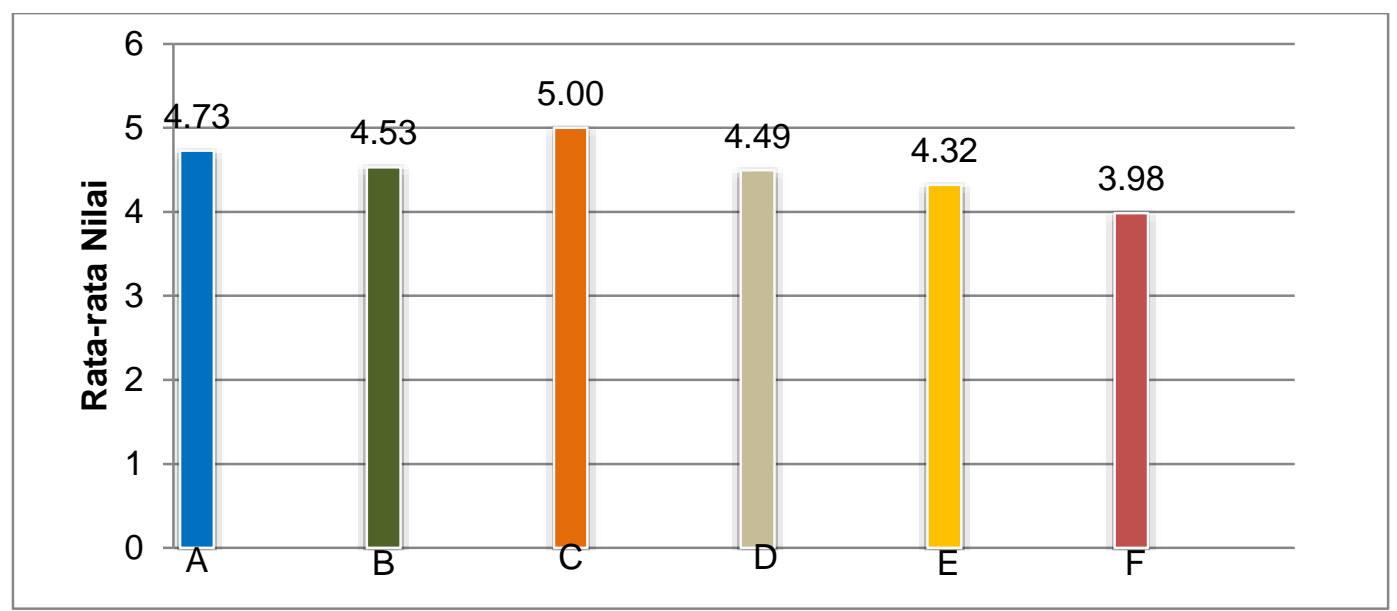

Gambar 4. Profil Pencapaian Keterampilan Proses Siswa pada tahap Inquiry Activity

Keterangan:
A : Menyiapkan Eksperimen
B : Melaksanakan Eksperimen
$\mathrm{C}:$ Mengumpulkan Data
D : Menganalisis Data
E : Pembahasan
F : Kesimpulan

Berdasarkan data pada Gambar 4 tampak bahwa perolehan skor pada keterampilan proses sains dalam mengumpulkan datan mendapatkan skor tinggi diantara keterampilan proses sains yang lain pada tahap inquiry Activity yaitu sebesar 5.00 kategori sangat baik. Sedangkan perolehan skor rendah terletak pada keterampilan proses sains dalam menuliskan kesimpulan yaitu sebesar 3.98 kategori baik. Meskipun pada keterampilan proses sains dalam menuliskan kesimpulan pada kategori baik akan tetapi pada saat pelaksanaannya siswa masih merasa kebingungan untuk menyimpulkan hasil eksperimen meskipun petunjuk yang diberikan sudah jelas. 


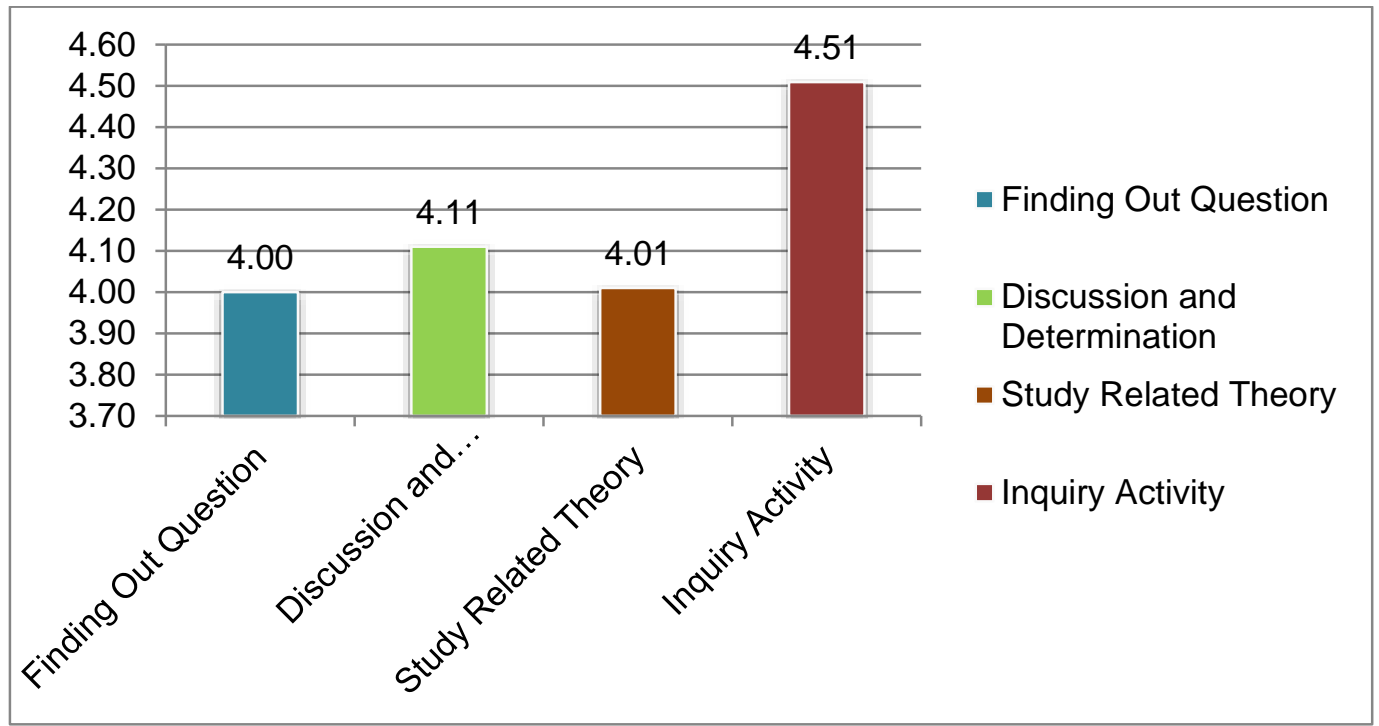

\section{Gambar 5. Profil Keseluruhan Pencapaian Keterampilan Proses Siswa model pembelajaran CNP}

Berdasarkan Gambar 5 tampak bahwa dari keempat tahapan model pembelajaran CNP yang terdapat pada LKS Inquiry Activity tahap Inquiry Activity memiliki skor penilaian yang tinggi diantara tahap yang lain yaitu 4.51 dengan kateori sangat baik. Sedangkan tahapan yang masih rendah adalah tahap Study Related Theory dengan skor 4.01 dengan kategori baik. Hal ini disebabkan karena, siswa belum tebiasa dalam merencanakan hipotesis dan mencari informasi untuk memperkuat hipotesis yang mereka tuliskan.

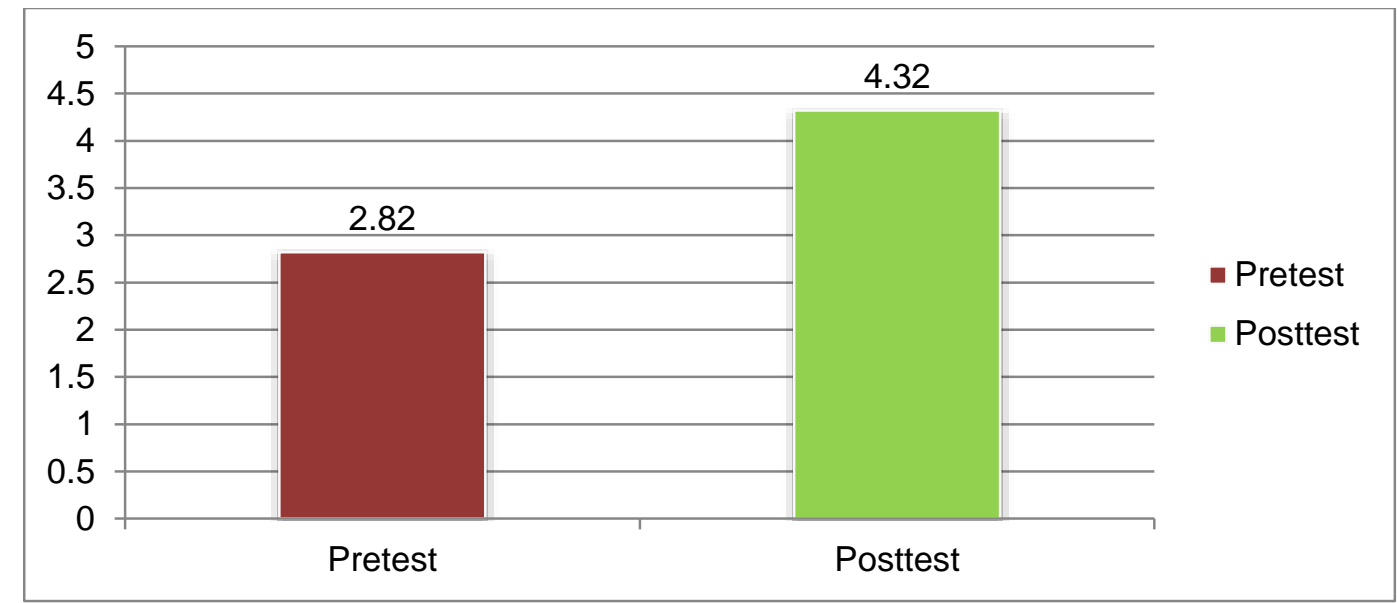

Gambar 6. Peningkatan Kemampuan Kogntif Siswa dalam menggunakan LKS Inquiry Activity berbasis model pembelajaran CNP model pembelajaran CNP 
Fatimah Primadian Farumananda, Agus Yulianto, Budi Astuti / Phenomenon Vol. 08, No. 1, Juli 2018

Berdasarkan data pada Gambar 6 tampak bahwa perolehan skor rata-rata pretest sebesar 2.82 sementara skor rata-rata posstest sebesar 4.32. secara umum hal ini menunjukkan bahwa LKS Inquiry Activity berbasis model pembelajaran CNP setelah melaksanakan proses pembelajaran dapat meingkatkan kemampuan kognitif siswa.

\section{Tanggapan Siswa terhadap model pembelajaran berbasis CNP}

Secara umum siswa memberikan tanggapan positif terhadap LKS Inquiry Activity berbasis model pembelajaran CNP. Siswa berpendapat bahwa LKS yang digunakan telah memberi kesempatan kepada siswa untuk ikut terlibat dalam proses pembelajaran dan bereksperimen seperti layaknya ilmuwan. Hal ini ditunjukkan dari hasil nilai angket respon siswa terhadap LKS Inquiry Activity berbasis model pembelajaran CNP yaitu sebesar 3.57 dengan kategori baik.

\section{SIMPULAN}

Berdasarkan hasil analisis data dan pembahasan dapat disimpulkan bahwa model pembelajaran berbasis CNP dapat mengetahui profil pencapaian keempat aspek keterampilan proses sains siswa yaitu pencapaian keterampilan proses sains siswa dalam Finding Out Question, Discussion And Determination And Study Related Theory yang masuk dalam kategori baik dengan skor masing masing adalah 4,00, 4,11, dan 3,53. Untuk keterampilan Inquiry Activity masuk dalam kategori sangat baik dengan skor 4,50 .

Sementara, kemampuan kognitif siswa mengalami peningkatan setelah mengunakan bantuan LKS Inquiry Activity berbasis model pembelajaran CNP dengan skor nilai rata-rata posttest sebesar 4.32 dengan kategori baik. Selain itu, respon siswa teradap penggunaan LKS Inquiry Activity berbasis model pembelajaran CNP memperoleh respon yang baik sebesar (3.57). Hal tersebut mengindikasi bahwa LKS Inquiry Activity berbasis model pembelajaran CNP dapat membantu siswa untuk mengetahui profil pencapaian ketrampilan proses sains dan baik digunakan pada saat proses pembelajaran. 
Fatimah Primadian Farumananda, Agus Yulianto, Budi Astuti / Phenomenon Vol. 08, No. 1, Juli 2018

DAFTAR RUJUKAN

Arikunto, S. (2006). Prosedur Penelitian. Bandung: PT. rineka Cipta

Depdiknas. (2006). Kurikulum Tingkat Satuan Pendidikan KTSP. Jakarta: departemen pendidikan nasional

Indrawati. (1999). Keterampilan Proses Sains, Tinjauan Kritis dari Teori ke Praktis. Bandung: PPPG IPA

Kinanti P. (2015). Pengembangan LKPD Study Related Theory Berbasis Model Pembelajaran Curious Note Program (CNP) Guna Memfasilitasi Kemampuan Peserta Didik dalam Memperoleh Pengetahuan Sains, Menyusun Kajian Teori, dan Merumuskan Hipotesis pada Materi Hukum Gravitasi Newton. e-journal UNY Edisi 4. Volume 4 . No. 2

Mundilarto. (2002). Kapita Selekta Pendidikan Fisika. Yogyakarta: Jurusan Pendidikan Fisika UNY.

Park, dkk. (2009). Development and Application of Curious Note Program TeachingLearning Model (CNP Model) for Enhancing the Creativity of Scientifically Gifted Students. Disajikan dalam International Science Education Conference (ISEC) di National Institute of Singapore pada tanggal 24 - 26 November 2009. Editor : Mijung KIM, dkk.

Purwoko Haryadi S. (2015). Pengembangan LKPD Discussion And Determination Berbasis Model Pembelajaran Curious Note Program Pada Materi Hukum Newton Tentang Gravitasi. e-journal UNY Edisi 4. Volume 4 . No. 1

Sanjaya, W. (2006). Strategi Pembelajaran. Jakarta: Kencana Prenada Media Group. Semiawan, C (1992). Pendekatan Keterampilan Proses. Jakarta : PT Gramedia.

Widiyoko, Eko P. (2011). Teknik Penyusunan Instrumen Penelitian. Yogyakarta: Pustaka Pelajar. 